\title{
Sexuality of people with intestinal ostomy
}

\author{
Sexualidade de pessoas com estomias intestinais \\ Sexualidad de personas con estomas intestinales
}

Danyelle Braga Rodrigues Cardoso ${ }^{1}$, Camilo Eduardo Almeida ${ }^{2}$, Mary Elizabeth de Santana ${ }^{3}$, Dione Seabra de Carvalho $^{4}$, Helena Megumi Sonobe ${ }^{5}$, Namie Okino Sawada ${ }^{5}$

Objective: to describe the experience of sexuality and other everyday life aspects for people with intestinal ostomy. Methods: qualitative, descriptive study with ten participants of the Specialized Reference Unit who gave interviews with inductive content analysis. Results: the established themes were Physical, emotional and socio-cultural changes, Changes in the exercise of sexuality of people with intestinal ostomy and Importance of the interdisciplinary support of the new sexuality. These changes are linked to body image, the self-esteem and interpersonal relationships with the partner, family and friends, going beyond the visible with the emergence of fear, rejection, difficulty with new relationships, body shame, embarrassment by the collector equipment, fear of the sexual act causes damage to the stoma and difficult to talk about the condition. Conclusion: the ostomy condition requires adaptation process, requiring trained interdisciplinary team in physiological and psychosocial problems resulting from surgical and therapeutic adjuvant treatment, which hinder the sexuality of these individuals.

Descriptors: Nursing; Sexuality; Colostomy; Ileostomy.

Objetivo: descrever a experiência da sexualidade e outros aspectos do cotidiano de pessoas com estomias intestinais. Métodos: estudo descritivo qualitativo, com dez sujeitos, da Unidade de Referência Especializada, que concederam entrevistas, com análise de conteúdo indutiva. Resultados: os temas estabelecidos: Mudanças físico-emocionais e socioculturais, Alterações no exercício da sexualidade de pessoas com estomias intestinais e Importância do suporte interdisciplinar sobre a nova sexualidade. Estas mudanças vinculam-se à imagem corporal, à autoestima e às relações interpessoais com parceiro, família e amigos, ultrapassando o visível, com surgimento de medo, rejeição, dificuldade com novos relacionamentos, vergonha corporal, constrangimento pelo equipamento coletor, medo que o ato sexual cause danos à estomia e dificuldade em falar sobre a condição. Conclusão: a condição de estomizado requer processo de adaptação, com necessidade de equipe interdisciplinar capacitada em relação aos problemas fisiológicos e psicossociais decorrentes do tratamento cirúrgico e terapêuticas adjuvantes, que dificultam a sexualidade destes sujeitos.

Descritores: Enfermagem; Sexualidade; Colostomia; Ileostomia.

Objetivo: describir la experiencia de la sexualidad y otros aspectos del cotidiano de personas con estomas intestinales. Métodos: estudio descriptivo, cualitativo, con diez sujetos, de la Unidad de Referencia Especializada, que concedieron entrevistas, con análisis de contenido inductivo. Resultados: temas establecidos: Cambios físicos, emocionales y socioculturales; Alteraciones en el ejercicio de la sexualidad de personas con estomas intestinales; e Importancia del apoyo interdisciplinario sobre la nueva sexualidad. Estos cambios están relacionados con imagen corporal, autoestima y relaciones interpersonales con amigos, que ultrapasan lo visible, surgiéndose el miedo, rechazo, dificultad con nuevas relaciones, vergüenza del cuerpo, del equipo recolector, miedo de que el acto sexual cause daño para estoma y dificultad de hablar sobre la condición. Conclusión: la condición de estomizado requiere proceso de adaptación, con necesidad de equipo interdisciplinario capacitado para enfrentarse problemas fisiológicos y psicosociales resultantes del tratamiento quirúrgico y terapéutico adyuvantes, que dificultan la sexualidad de estos sujetos.

Descriptores: Enfermería; Sexualidad; Colostomía; Ileostomía.

\footnotetext{
${ }^{1}$ Hospital Municipal de Castanhal Pará. Castanhal, PA, Brazil.

${ }^{2}$ Estratégia Saúde da Família Santa Izabel. Belém, PA, Brazil.

${ }^{3}$ Universidade do Estado do Pará. Belém, PA, Brazil.

${ }^{4}$ Serviço de Atenção à Pessoa Estomizada da Unidade de Referência Especializada em Saúde. Belém, PA, Brazil.

${ }^{5}$ Escola de Enfermagem de Ribeirão Preto, Universidade de São Paulo. Ribeirão Preto, SP, Brazil.

Corresponding author: Mary Elizabeth de Santana

Avenida José Bonifácio, 1289. São Braz. CEP: 66063-075. Belém, PA, Brazil. E-mail: betemary@terra.com.br
} 


\section{Introduction}

Sexuality is a human experience involving emotion, pleasure, communication, affection, and others. Sexuality goes beyond the physiological need and a desire symbology. It cannot reduce to anatomical aspects, transcending to physical definitions and permeates every moment of life with complex, multifaceted and unique meanings ${ }^{(1)}$.

Sexuality influences self-esteem by being closely linked to body image, being the way the body is perceived by the person ${ }^{(2)}$. The image covers the vision, the emotional, social and physiological experiences of the person on his body, which is multidimensional and dynamic $^{(3-4)}$.

In modern society, the growing overvaluation of the body is undeniable on expectations for social inclusion and even to obtain power. The frantic search for the ideal body is stimulated by the media and "beauty industry" because everybody seek to do everything to fit the pre-established cultural patterns.

However, those who have no aesthetic profile are victims of prejudice and discrimination. This reality can be aggravated even more when there is loss of the perfect physical body associated with the illness, which results in mutilatory consequences, especially in oncological diseases ${ }^{(5)}$.

Colorectal cancer in Brazil for 2014/2015 is estimated of 15,070 new cases in men and 17,530 in women. To the northern of Brazil, colorectal cancer is the most incident in both genders, with about 360 new cases in men and 430 in women ${ }^{(6)}$.

The therapy for colorectal cancer involves surgery, antineoplastic chemotherapy and radiation therapy, alone or in combination. Treatment depends on the stage of the tumor for resection and construction of a permanent ostomy, because many patients are unaware or are not informed about the treatment and its consequences regarding the elimination patterns, eating habits and hygiene, use of equipment, sexual activity, sleep patterns and body image ${ }^{(7)}$.

Intestinal ostomy made in the large intestine are called colostomy and can be definitive due to oncological diseases in advanced stage, irreparable trauma of the pelvic floor, congenital conditions and serious medical conditions ${ }^{(8)}$.

The physiological effects of surgery for ostomy involve the diversion of disposal into the abdomen, causing sphincter loss with deprivation of fecal control, involuntary elimination of gases and odors, which may also have changes in sexual stimulus, where men may experience erectile dysfunction, ejaculatory disorders and infertility, and women may have inhibited sexual desire, lack of lubrication in the vagina and dyspareunia ${ }^{(9)}$.

Therefore, the oncological illness brings double impact in people's life, healing uncertainty and the possibility of imminent death; the impact caused by deterioration of body image, shame and fear of rejection ${ }^{(7)}$. Thus, an ostomy generates a visible and significant physical change in the body, which causes loss of integrity, dynamism and autonomy, causing personal and social conflicts, especially with the outside world relationships.

Knowing these changes in people with intestinal ostomy and the repercussions on sexuality by health professionals who provide care to these patients, it may contribute to the improvement of care with the use of more appropriate strategies to the demands of specific needs. Given this context, we ask: How is the experience of people with intestinal ostomy regarding their sexuality?

This study aims to describe the experience of people's sexuality with intestinal ostomy.

\section{Method}

Descriptive study of qualitative approach developed in the Care Service to the Person with ostomy, which works on the premises of Health Specialized Reference Unit Presidente Getúlio Vargas in the city of Belém do Pará.

There were 10 subjects with intestinal ostomy participating in this study, who were selected by 
inclusion criteria: having permanent stoma for over a year, both genders, adults, married, widowed or divorced with or without partners.

Data collection was from April to July 2014. Three meetings were held mediated by the nurse, considering the days scheduled for the equipment search, since the average attendance was 12 permanent intestinal ostomy and family members (spouse or partner) per day. The interviews were scheduled according to the availability and convenience of ostomy patients in the unit in a private room, with an individual interview duration of 30 minutes with audio recording. Two researchers with mediation of a program's nurse conducted all interviews.

The fieldwork involved a period of two months, carrying out non-participant observation, diary field and three group meetings for inclusion in the service context, as well as individual interviews at the end, with the following guiding question: What is your experience with sexuality after colostomy/ileostomy? In addition, sociodemographic data (origin, age, gender, religion, education, occupation and monthly income) and clinical data were collected (diagnosis, type and time of ostomy).

The data obtained by the interaction with the group, as well as the interviews were transcribed in Word ${ }^{\circledR}$ program, composing an independent single set of gender of the subjects data, which were analyzed by following the steps of inductive content analysis ${ }^{(10)}$, consisted on pre-analysis, material exploration and interpretation of data by establishing themes.

Participants were identified by alphanumeric code with the letter "I" of interview and the sequence number of the interviews (I1, I2...). The project was approved by the Ethics Committee in Research on Human Beings of the "Magalhães Barata" Nursing School in Pará State University, under number 541,288 . It is noteworthy that all the information and the purpose of the study were provided with clarification of questions from participants, who signed the Informed Consent Form on two copies, one for the participant and one for the researcher. Ethical precepts were assured according to Resolution $466 / 12$ of the National Health Council.

\section{Results}

From the 10 subjects with intestinal ostomy, six were male and four were female. Most of them were aged $\geq 60$ years. In relation to the marital status, four were married. As for subjects education, four had complete elementary school, three had complete high school, two had university graduation and one was illiterate. Concerning to labor activities, six were retired, one was a cook, one was a businessman, one was an upholsterer and one was an engineer. Regarding to family income, seven received $>7$ minimum wage.

With regard to religion, five were Catholics, three were Evangelical and two had not religion. Regarding the type of ostomy, nine had permanent colostomy and one had ileostomy, three of them had this condition between one and five years, one of them between six and ten years, two of them between eleven and fifteen years, four of them had it for more than sixteen years due to colorectal cancer for five subjects, inflammatory bowel disease for three subjects, poor intestinal congenital training for one subject and intestinal parasite for one subject.

\section{Theme 1: Physical, emotional and socio-cultural changes}

Sexuality aspects have been measured by the intestinal ostomy: It has to change, but it does not make sense. What was normal becomes different, so it has to change (I3). I3 explains that changes were inevitable because the surgery altered the intestinal path, with visible change to the abdominal region, which specifically makes it different from others.

The cultural pattern of the woman favors loss of self-esteem, since when dealing with ostomy, the people's attention is focused on values related 
to intestinal elimination that now goes against the known normality, as if the person starts handling with contaminated things: People look and wonder what you have... If you have 5 fingers on your right hand and four on the left hand, the person only looks at your left hand, right? And, with regard to disguise... You try to disguise the volume that the collection bag causes, because there is not only the bag, there is also the plate on the skin, making it more higher... And, you are always concerned for not leaving any odor from the bag (gases) ...it leaves you shy (I4).

The disharmonious image with mirror reflects the real image of the person, showing all feeling and painful suffering of the disease process, treatment by making the stoma. This body mark will not let the person forget about how much is different from other people, causing low self-esteem and mechanisms to hide the stoma from himself and those around him: I do not like looking at my belly, it is horrible to see it hanging there... I find the scar ugly, I do not like looking in the mirror (I7). When I looked myself in the mirror, it looked like I was not going back to being a woman, return to life, not getting well dressed to go out... (I2).

To be accepted by the society, the ostomy patients give up their likes and habits, changing the way they dress, trying to hide the stoma. Such body changes will only be overcome from the adaptation to their new condition and then, they need multidisciplinary support, which reflect the physical and psychological behavior, minimizing and enabling him to face the daily difficulties, such as: I have changed my way of dressing, I used to like slinky clothes very slinky and today, I use them wide. To be able to wear slinky clothes, I avoid eating certain things, I just have a snack to go out (I7).

These modifications made by the ostomy are experienced in daily life: As I arrive in front of the mirror and look at myself, despite having a bag, having scars, I know that I am happy because I am a very successful person... I perceive myself a woman, ready to go on living. I feel good, I feel beautiful, despite my limitations (I9).

On the other hand, the strategies used to deal with changes in the body image, such as isolation attitudes for fear of rejection and fear of sexual intercourse, which influences the attitude towards the people around them: I was close-minded for people to know me better and people did not know what I had... I have been three years, closed, distant, but then I saw that I had to open up.... (I2). I did not want to go out, because I did not accept it at first, I thought no one could see me with this... I was about two years without leaving home... (I7).

It is also important to highlight the role of social interaction in the physical adaptation of the ostomy process. Thus, the interdisciplinary team should be aware of changes the people with ostomy, their partners and family go through, so feelings such as fear, prejudice and low self-esteem are not cultivated, but can be overcome. Thus, people can be free to experience their sexuality without imposing limits, enjoying it with various possibilities of expression that human being is capable to be happy: ...The family has to be supportive, and the partner too... but the person has to help himself (I3).

\section{Theme 2: Changes in the exercise of sexuality of people with intestinal ostomy}

In addition to the physical and socio-cultural changes, with the rectum amputation for a permanent ostomy, other sexual dysfunctions result from nerves responsible for erection and/or ejaculation. In females, dyspareunia can occur due to loss of elasticity and reduced vaginal lubrication. These factors further complicate the physiology of sexual intercourse. This was highlighted by: I was very worried about ejaculation that did not occur... Everything that affects the physical and psychological does not let us forget the problem (I4). Erection, I almost did not have, I have a lot of pain in the penis, it is almost atrophied, it is sensitive ... I am unable to have sex... (I6).

In the treatment of women with cancer, dyspareunia may occur, but the problems reported were related to self-esteem due to change in body image.

The change in bodyimage hinders theadaptation to the new condition of life, since it compromises the performance of social expectations on women and culture of the perfect body: I feel diminished about everything ... For other women, I feel greatly diminished... (I7). 
During the sexual act, there is a concern about the equipment and possible complications: In my case, I'm psychologically prepared, even for a rejection of my partner, because I thought about my difficulty and my disease (I6). My concern was that people refuse me because of my problem, but they treated me very well! Totally different from what I thought when I was in the hospital (I5).

This fact is most evident during the first sexual intercourse after ostomy, since the individual is going through a rediscovery period as having an ostomy. In addition, there are situations where there are other limitations of the patient, such as lack of psychological support and clarification about sexuality, which could affect the affective/sexual and confidence relationship, as in: after four months of surgery, I had my first sexual intercourse... I was afraid ...(laughs), I was afraid the bag could come out... (I7).

For sexuality approach, there are other fundamental aspects such as personal relationships, family and friendship, involving situations of sexual intimacy, dating and marriage, relationship with the partner and feelings of self-esteem that can encourage participation in social situations because for: $A$ woman with ostomy is no different from other women, because it has only changed her intestinal transit. But, the heart, sexual desire, it depends on how your partner will touch you. Because you needs to be with someone who respects you, she is affectionate, who likes you as you are... it's not only the body, but our character, our way of thinking, living... (19).

In addition to the fear of rejection, the person with ostomy expressed the difficulty of relating with a partner, considering being in part responsible in maintaining their difficulties to greater intimacy as pointing out: Then this problem... I'm feeling like a rejection but I wince myself. I can get to an intimate relationship, I'll have to undress, then the shock will be violent for a partner (I3).

On the other hand, the attitude of ending a relationship from the person with ostomy is like this, not giving the partner the opportunity to decide: ...We started dating, and at that time... I was embarrassed...(laughs). Talking he said: It is not because of this that I'll leave you, we have to continue to be friends even with a bag, stop knowing each other, stop trying... and he accepted me the way I am... (I2).
Living with the ostomy bag generates conflicting feelings, concerns and difficulties to deal with this new situation. There are emotional stages co-responsible for the decline in self-esteem, causing sense of mutilation, self-rejection and others, resulting in confused attitudes usually directed to closest and emotionally important people, but these things modify the couple's relationship as emphasized in: Then, she was there with me a long time, took care of me... she wanted, but then, prejudices appeared when I left the hospital ... it's complicated... (I8). I had a partner... She supported me but then, I did not want her anymore... I got sick of her. I did not want to see her face. He spent nights and sleepless nights with me, companion of my pain, every little thing. She did the cleaning of the bag, everything... But I began to see her more like a friend than as a woman... She tried, but I did not want to... (I5).

One of adaptation strategies for the ostomy person is adopting positions that are more comfortable during sexual intercourse, and get sexual satisfaction. This adaptation process promotes sexuality of ostomy patients, enabling to experience it without fears and concerns about the collector equipment as reported in: The traditional position is uncomfortable for both two people, changing the position... not to bring harm, nuisance and vice versa (I4).

Sexual changes in ostomy people are so strong that the sexual act becomes secondary to some participants, loosing their libido, erectile dysfunction, pain, among others: I had a normal sexual relationship and today I have not because I have pain. And that brings problems for her too. I try to avoid it, because if I keep petting, touching... It may be that I satisfy her, but I will not be satisfied... (I6).

\section{Theme 3: Importance of the interdisciplinary support of the new sexuality}

The reports of the participants of this study indicated a demand for needs related to sexuality, which bring several repercussions on biopsychosocial and cultural dimensions, implying the need for interdisciplinary support as outlined in: I believe no one talks about this "thing" (sexuality) in the hospital, because if I had 
someone to talk about it, it would be better, it would help a lot... (I8).

These patients fear embarrassment or are not sure about this topic being discussed during treatment, especially by the priority given to emerging therapeutic problems: With guidance (sexuality), I would feel safer, for sure... (I5). I find guidance on sexuality important, because it helps in the person's head, even more than the person thinks a lot of nonsense things. I think a lot of nonsense... So, the more information, the more the person's head improves... (I8).

\section{Discussion}

The results from the study indicated that these participants faced many adversities, especially with regard to changes from surgical treatment and adjuvant therapies, especially for ostomy people by oncological diseases.

Sexuality is considered as a pillar of quality of life, with multidimensional character, that is, it is not influenced only by anatomical and psychological factors, but mainly psychosocial and cultural factors, measuring interpersonal relationships and life experiences within the family and society where they live. Thus, the sexuality of the participants with intestinal ostomy was analyzed by the biopsychosocial and cultural changes after the creation of the stoma ${ }^{(11)}$.

The physical aspect is related to physiological and body image changes of ostomy participants, causing them to have a new experience of their sexuality. This results from the surgery making the intestinal ostomy, with loss of bodily integrity, violation of social rules on hygiene, and the sphincter loss and its control, which indicates a characteristic of adulthood ${ }^{(12)}$. The surgery making the intestinal ostomy already gives changes in sexuality, since ther are changes in fecal via with the presence of a hole in the abdomen through which eliminate feces and need to use collectors equipment, making the person feel different from the other ${ }^{(11)}$.

On the other hand, the erectile dysfunction and ejaculation problems are the main difficulties faced by ostomy men because for them sexuality is related to the sexual act itself. When considering that the participants underwent the surgery with permanent ostomy, there is greater possibility of male genital tract commitment, negatively affecting their sexuality ${ }^{(13)}$.

The comparison regarding women's body image shows the cultural background determined by society, that despite the disease, it seems that she has the obligation to comply with social requirements, facing with their conflicts and fantasies due to her image about her body, but also the image society have from her, people around her ${ }^{(14)}$. Thus, the body is culturally analyzed as a whole, which associates the physical to the emotional (feelings), representing something that happens in the body itself ${ }^{(15-16)}$.

Some permanent ostomy patients reported no having problems with body image, as they accept the stoma as the possibility of being alive, because they perceive that despite their limitations, they can achieve what they wish, as this condition does not incapacitate them as people and for life ${ }^{(17)}$.

The ostomy people experience a grieving process in the postoperative period of making the stoma, especially by comparing the before and after, to redraw the biopsychosocial changes and seek strategies to adapt to the new normality ${ }^{(18)}$.

It is considered that the ostomy process causes strangeness being a socially unknown therapy and, moreover, fear of bias and social stigma associated with oncological disease and the deficiency lead them to the isolation, fear of rejection by their partners, friends and society in general, with the adoption of new behaviors and ongoing concern ${ }^{(19)}$.

The constant fear of rejection causes the person to adopt attitudes and behaviors to defend in advanced, once he recognizes his limitations, and thus moving away from people in general, before it comes worse, that is performing negative outlook of the future. However, this is not always materialized ${ }^{(19)}$. In addition, the pessimistic view of themselves results in the absence of an initiative regarding sexuality, mainly because it involves body exposure, leading to a feeling of continuous mutilation ${ }^{(18)}$. 
Their partner's support is essential for the development of positive attitudes to the new situation, making it easier and faster return to sexual activity as well as the adaptation of the couple for the experience this time in a more pleasant way ${ }^{(17)}$.

Partner's acceptance enables to establish the new identity as a ostomy person without losing possible adaptations for maintaining their daily and interpersonal activities, leaving aside the pessimistic view about their new condition as a not worthy human being of a lifetime. Many times, the ostomy person is surprised by the accepting attitude of his/ her partner ${ }^{(11,13)}$.

Conflicts of both the ostomy person as the partner may include various aspects such as changing body image, self-esteem because of the harm and the conflicting feelings of desire, revulsion, disgust and compassion $^{(18)}$.

The ostomy patients who had hard time relating to the illness, make a reflection on their life and the process of adaptation, in which there was a transformation of the relationship with the partner, bringing changes in maintaining or not the relationship ${ }^{(19)}$.

The results showed changes in the sexual life of ostomy patients resulting from the dysfunction and therefore the need to control their desires, avoiding the affection, touching, not to get frustrated. This is a major complicating factor for intimate life of the couple, since for the woman, the love, affection and feel contribute to obtaining pleasure, but for a man pleasure is linked to the sexual act. Thus, as not satisfying their sexual needs, they commit their partner's, causing dissatisfaction in both. In the absence of care and affection, the ostomy patients and their partners feel isolated, anxious or depressed, inadequate or emotionally distant ${ }^{(9)}$.

In this way, partner's support is essential for the ostomy person to adapt to their condition, making the process easier and faster. The social and family support favors facing the difficulties and helps for the restructuring of daily activities ${ }^{(20)}$. The experience of intestinal ostomy regarding sexuality involves reflections on the assistance to these patients, especially in the nursing perspective.

Considering health care for intestinal ostomy being secured by specific legislation such as Decree Number 400 of November 2011, which recommends multidisciplinary care, linked to the outpatient followup and supply of collectors and adjuvants equipment. It also provides adequate space to facilitate exchange of experiences among ostomy patients and family to assist in the rehabilitation and reintegration and family life and society ${ }^{(19)}$, which refers to the discussion about the quality of this assistance.

Sexuality is not a common aspect to be addressed by health professionals in both the inpatient and outpatient context, and sometimes omitted or discussed superficially in meetings with patients because health professionals have fear of embarrassment or cause embarrassment in patients. Thus, professionals need knowledge and skills development to address the issue. Professionals seeking to provide support to patients from diagnosis of colorectal cancer to the ostomy, with specialized follow-up in the clinic ${ }^{(20)}$.

Perioperative assistance should focus preoperative education, physical and emotional preparation for surgery and its consequences to minimize suffering, reducing anxiety and preventing complications after surgery. In postoperative, teaching is intended for ostomy care at home, in addition to referral to the public program, in which the patient will have access to purchase collectors equipment and expert assistance. Specifically for nursing, which aims to provide holistic care to all patients and regarding to sexuality, their interventions should include sex changing of patients undergoing cancer treatments and ways to adapt to the ostomy new condition.

The results showed the expectation that the ostomy patient has towards professionals in approaching sexuality, considering the necessary 
emotional support that make them feel safe, to minimize the fears of the unknown, and rediscovering their sexuality. The professionals will address the uncertainties, doubts and fears that need to be clarified to facilitate the adaptation of this individual.

To approach the sexuality by professionals, it will be necessary to develop skills, such as sensitivity, knowledge and appropriate time to address on sexual guidance, age of patient, disease level, and questions and educational information to suit the needs of the patient to start interaction.

This may encourage patients and their partners feeling more comfortable discussing this topic, which requires professional assessment, intervention models and developing appropriate strategies to the specific demands of each patient. The nurse is the professional who maintains greater contact with the patient at all stages of treatment and thus can address the sexuality and dysfunctions related to disease and adverse effects of therapies as well as listen objectively, presenting information related to symptoms and treatment, clarifying issues and concerns by providing appropriate referrals, with systematic evaluation.

With the analysis of participants' reports about changes of sexuality related to physical appearance, we may infer that such changes are linked to sexual dysfunction and body image. Regarding the sexual dysfunction, we see problems of this order only in ostomy men due to erectile dysfunction. However, for women the difficulties were related to body image.

The body image problems occur due to the new body reality, needing new cultural construction about their sexuality, considering the physiological changes and a social and cultural redefinition. On the other hand, another important challenge is to expose their condition to the partner and generally occur situations that involve rejection, humiliation and rejection, which can be painful.

Therefore, there are defense mechanisms that can be adopted by both sides of the relationship, both for the one with an altered body image as the partner who must deal with incongruent feelings of desire and compassion, but also disgust and revulsion. In the testimonies analysis we found that the partner of the ostomy patient supported him, carrying with ostomy care, however, we find that there is the possibility of the partner manifest prejudice and rejection attitudes. Moreover, we observed that both the partner as the family play a key role in the re-elaboration of their sexuality.

When addressing the multidisciplinary team on the sexuality of ostomy patients, there in a need of partner and family integration.

\section{Final Considerations}

Intestinal ostomy patients need to resume their sexuality with the new condition, which requires professional knowledge and skill development to address and provide adequate support.

We emphasize that the changes in sexuality are directly linked to body image, reflecting the selfesteem and interpersonal relationships with their partners, family and friends.

The consequent modifications to intestinal ostomy go beyond the visible, with emotional changes, affecting the life of ostomy patients, especially by sexual dysfunction and feelings of fear, rejection in sexual intercourse, difficulty in developing new relationships, isolation attitudes, ashamed to expose their body, fear of embarrassment situations of going out the collector equipment, fear that the sexual act causes damage to the stoma and also difficult to tell about their condition. That is, it is a period of rediscovery and adaptation to the new situation as a ostomy patient.

The sexuality approach in intestinal ostomy patients requires a multidisciplinary team trained for conducting and developing appropriate interventions at each stage of cancer treatment. The nurse can effectively contribute to the improvement of interventions on this subject for this people. 


\section{Collaborations}

Cardoso DBR e Almeida CE contributed in developing the research project, collecting, organizing, analyzing and interpreting the data. Santana ME accompanied the data collection, article construction, assisted in the review and directed the study. Carvalho DS contributed in data collection and transcription of the interviews. Sonobe HM and Sawada NO contributed to the organization, analysis and interpretation of data and article writing and final approval for publication.

\section{References}

1. Paula MAB, Takahashi RF, Paula PR. Os significados da sexualidade para a pessoa com estoma intestinal definitivo. Rev Bras Coloproctol. 2009; 29(1):77-82.

2. Seara LS, Vieira RX, Pechorro PS. Função sexual e imagem corporal da mulher mastectomizada. Rev Int Androl. 2012; 10(3):106-12.

3. Moreira H, Canavarro MC. A longitudinal study about the body image and psychosocial adjustment of breast cancer patients during the course of the disease. Eur J Oncol Nurs. 2010; 14(4):263-70.

4. Sabiston CM, Rusticus S, Brunet J, McDonough $\mathrm{MH}$, Hadd V, Hubley AM, et al. Invariance test of the multidimensional body self-relations questionnaire: do women with breast cancer interpret this measure differently? Qual Life Res. 2010; 19(8):1171-80.

5. Almeida TR, Guerra MR, Filgueiras MST. Repercussões do câncer de mama na imagem corporal da mulher: uma revisão sistemática. Physis. 2012; 22(3):1003-29.

6. Instituto Nacional de Câncer José Alencar Gomes da Silva. Coordenação de Prevenção e Vigilância. Estimativa 2014 - Incidência de câncer no Brasil. [Internet]. 2014 [citado 2015 abr 15]. Disponível em: http://www.inca.gov.br/estimativa/2014/ estimativa-24042014.pdf
7. Araújo AP, Lopes T, Decesaro MN. The Adjustments experienced by persons with an ostomy: An integrative review of the literature. Ostomy Wound Manage. 2014; 60(10):34-42.

8. Rocha JJR. Estomias intestinais - (ileostomias e colostomias) e anastomoses intestinais. Medicina [Internet] 2011 [citado 2014 jan 5]; 44(1):51-6. Disponível em: http://www.fmrp.usp.br/revista

9. Fleury HJ, Pantaroto HSC, Abdo CHN. Sexualidade em oncologia. Diagn Tratamento. 2011; 16(2):8690.

10. Câmara RH. Análise de conteúdo: da teoria à prática em pesquisas sociais aplicadas às organizações. Rev Interinstitucional Psicol. 2103; 6(2):170-91.

11. Alves RCP, Moreira KCR, Franco CPP, Oliveira DC. A percepção do paciente portador de ostomia com relação a sua sexualidade. Rev Interd. 2013; 6(3):26-35.

12. Polleto D, Silva DMGV. Living with intestinal stoma: the construction of autonomy for care. Rev Latino-Am Enfermagem. 2013; 21(2):531-88.

13. Barreto APCP, Valença MP. The sexuality of the patient with intestinal ostomy: literature review. Rev Enferm UFPE on line [Internet]. 2013 [cited 2014 Jan 5]; 7(7):879-87. Available from: http:// www.revista.ufpe.br/revistaenfermagem/index. php/revista/issue/view/79

14. Martins VV, Penna LHG, Paula MAB, Pereira CDC, Leite, HC. Sexualidade, estoma e gênero: revisão integrativa da literatura. Rev Estima. 2011; 9(1):39-46.

15. Batista MRFF, Rocha FCV, Silva DMG, Silva Júnior FJG. Autoimagem de clientes com colostomia em relação à bolsa coletora. Rev Bras Enferm. 2011; 64(6):1043-7.

16. Coelho AR, Santos FS, Dal Poggetto MT. A estomia mudando a vida: enfrentar para viver. REME Rev Min Enferm. 2013; 17(2):258-67.

17. Sousa CF, Brito DC, Branco MZPC. Depois da colostomia vivências das pessoas portadoras. Enferm Foco. 2012. 3(1):12-5. 
18. Barbosa BN, Gondimi ANC, Pacheco JS, Pitombeira HCS, Gomes LV, Vieira LF, et al. Sexualidade vivenciada na gestação: conhecendo essa realidade. Rev Eletr Enf. [periódico na Internet]. 2011 [citado 2014 jan 5]; 13(3):464-73. Disponível em: http://www.scielo.br/scielo.php?script=sci_ etoc\&pid=0034716720110006\&lng=pt\&nrm=iso
19. Souza JL, Gomes GC, Barros EJL. O cuidado à pessoa portadora de estomia: o papel do familiar cuidador. Rev Enferm UERJ. 2009; 17(4):550-5.

20. Çakmak A, Aylaz G, Kuzu MA. Permanent stoma not only affects patients' quality of life but also that of their spouses. World J Surg. 2010; 34(12):2872-6. 